\title{
Response of Antioxidant Substances and Enzymes Activities as a Defense Mechanism Against Root-Knot Nematode Infection
}

\author{
Hossam S. EL-BELTAGI ${ }^{1,2}$, Ahmed A. FARAHAT ${ }^{3}$, Alsayed A. ALSAYED ${ }^{3}$, Nomer A. MAHFOUD \\ ${ }^{1}$ Cairo University, Faculty of Agriculture, Biochemistry Department, P.O. Box 12613, Gamma St, Giza, Cairo, Egypt \\ ${ }^{2}$ Vice-Rectorate for Graduate Studies and Research, SUDLS, King Saudi University, Riyadh \\ 11451, Kingdom of Saudi Arabia; lbltg@yahoo.com (*corresponding author) \\ ${ }^{3}$ Cairo University, Faculty of Agriculture, Zoology and Agricultural Nematology Department, P.O. Box 12613, Gamma St, Giza, Cairo, Egypt
}

\begin{abstract}
The organic amendments, composts (1,2,3), neem and poultry as well as inorganic fertilizers (NPK compound and commercial, A three') and the nematicide nemacur $10 \mathrm{G}$ applied singly were effective in reducing $M$. incognita number of galls, nematode reproduction and fecundity. The effectiveness seemed to be material origin dependent. Neem, compost 1, 3 (5 g/pot) gave the best results. Yet, achieved results were less than those of nemacur $10 \% \mathrm{G}$. The antioxidant substances content and enzymes activities due to nematode infection and application of organic and inorganic fertilizers pointed to significant increase of lipid peroxidation and hydrogen peroxide as a result of nematode infection and nemacur treatment. While all organic and inorganic fertilizers reduced such materials with significant differences among treatments. Likewise, nematode infection resulted in slight but significant increase in glutathione and ascorbic acid in tomato shoots and roots. All treatments increased antioxidant substances comparing to healthy and infected plants. Glutathione-Stransferase activity highly increased in infected roots but the lowest activities were achieved by organic fertilizers. Nematode infection and nemacur treatment increased slightly phenylalaine ammonia lyase activity but enormous increase was observed in shoots and roots of treated plants with organic fertilizers followed by NPK treatments.
\end{abstract}

Keywords: antioxidant enzymes, lipid peroxidation, Meoildogyne incognita

\section{Introduction}

Plant endoparasitic nematodes, spend a major part of their life cycles embedded in the roots of a host plant and are therefore exposed to a variety of host defense responses (Jones et al., 2007). These responses may include generation of damaging reactive oxygen species (ROS). Reactive oxygen species (ROS) such as superoxide anion $\left(\mathrm{O}_{2}{ }^{-}\right)$, singlet oxygen $\left({ }^{1} \mathrm{O}_{2}\right)$, hydrogen peroxide $\left(\mathrm{H}_{2} \mathrm{O}_{2}\right)$ and the hydroxyl radical $(\mathrm{OH})$ are produced continuously as byproducts of various metabolic pathways that are localized in different cellular compartments (Reddy et al., 2005). However, under stressful conditions, their formation might increase to excess the antioxidant scavenging capacity, thus creating oxidative stress by reaction and damage to all bio-molecules (Halliwell and Gutteridge, 1999). In addition, ROS are highly reactive to membrane lipids, protein and DNA. They are believed to be the major contributing factors to stress injuries and to cause rapid cellular damage particularly when plants are exposed to stress conditions such as chilling stress, salt stress, Fe deficiency, heavy metals stress, drought stress, heat stress, ionizing radiation, phytophagous mites, such as Tetranychus urticae Koch, Peanut Mottle Virus and root-knot nematode, Compared to animal parasitic nematodes, little is known about the defence proteins employed by plant parasitic nematodes (Afify and El-Beltagi, 2011a, 2011b; Afify et al., 2011a, 2011b; Aly and El-Beltagi, 2010; ElBeltagi and Mohamed, 2010; El-Beltagi et al., 2008, 2010, 2011a, 2011b; Eriyamremu and Lolodi, 2010; Essemine et al., 2010; Hefny and Abdel-Kader, 2007; Ibrahim et al., 2011; Kobeasy et al., 2011; Mohamed et al., 2009; Salama et al., 2009; Saleh, 2007; Shehab et al., 2010). Superoxide dismutase, catalase and ascorbate peroxidase activity have been detected in some endoparasitic nematodes but little is known about the roles of these proteins in the hostparasite interaction and none of these proteins has been characterized in detail. There is no information regarding peroxiredoxins in plant parasitic nematodes (Molinari and Miacola, 1997).

Alterations of plant enzymes mainly peroxidase, polyphenol oxidase, catalase, superoxide dismutase and protease in the tissues of nematode infected, susceptible and resistant varieties were extensively studied. Such alterations differed in susceptible and resistant cultivars (Molinari, 1995; Sharma, 1993; Zacheo et al., 1987). The root-knot nematode infection increased peroxidase activity, phenol content, polyphenol oxidase activities, phenylalanine ammonia lyase, tyrosin ammonia lyase in roots of cotton, coffee, chick pea, banana and rice (Gregory and Michael, 1978; Mazzafera, 1989; Mishra and Mohanty, 2007; Patel et al., 2001; Sundararaju and Suba, 2006; Xu et al., 2008). 
In tomato, numerous reports in literature illustrate the influence of the root-knot nematode on roots phenol content, lipid peroxidation, antioxidants and peroxidase activities as defense mechanism against nematode infection (El-Sherif and El-Wakil, 1991; Kuzniak and Sklodowska, 2001). Phenol and ortho-hydroxyphenol levels increased in tomato roots infected with Meloidogyne incognita but the increase was greatest in the resistant cultivar (Farahat et al., 2012). Polyphenol oxidase activity also increased by $16-24 \%$ in resistant cultivars and by $12-18 \%$ in the susceptible one (Hasan and Saxena, 1997). Likewise, peroxidase activity increased in tomato resistant cultivars up to 5 times than that in healthy plants as measured 10 days after inoculation by $M$. incognita and decreased thereafter to normal levels within few days. Also, $M$. incognita resistant varieties of tomato had significantly higher peroxidase enzyme specific activity than the susceptible varieties (Shukla and Chakraborty, 1988). Similar results were recorded by previous study when peroxidase activity increased in both resistant and susceptible tomato cultivars infected with $M$. incognita, such increase was greater in resistant cultivars (Zacheo et al., 1993). Polyphenol oxidase (PPO) activity and indole-acetic acid (IAA) oxidase activity were higher in infected roots of both the susceptible ('Pusa Ruby') and the resistant ('Mangala') cultivars compared to respective healthy counterparts, although the magnitudes of both parameters were much higher in the susceptible 'Pusa Ruby' compared to the resistant 'Mangala' (Nagesh et al., 1998). IAA oxidase activity was observed to be lower in healthy and infected roots of 'Mangala'. However, few reports illustrate the role of organic matter in improving defense mechanisms of plants against the root-knot nematodes infection. Kesba and El-Beltagi (2012) reported that application of humic acid significantly reduced the lipid peroxidation (MDA) and $\mathrm{H}_{2} \mathrm{O}_{2}$ contents of grape rootstocks, while the antioxidant compounds glutathione (GSH) and ascorbic acid (ASA) contents were significantly increased when compared with the check. Antioxidant defense enzymes ascorbate peroxidase (APX), superoxide dismutase (SOD) and catalase (CAT) showed significant increase in their activities. Total phenol content and polyphenol oxidase (PPO) were improved significantly in treated plants compared to nematode treated check. The present study was carried out to answer the following question: could fertilizers (organic or inorganic) improve the defense mechanism of tomato against the root-knot nematode Meloidogyne incognita?

\section{Materials and methods}

\section{Compost and other organic and inorganic fertilizers}

One month old tomato seedlings cv. growing stage, with uniform size were transplanted singly in $15 \mathrm{~cm}$ clay pots filled with virgin sandy soil. One week after transplantation, Three types of compost 1, 2, 3, obtained and produced from Microbiology Department, Fac. of Agric.,
Cairo University (Rashad et al., 2010), dry leaves of neem, poultry droppings, NPK, A three ${ }^{\circledast}$ were applied singly at the rate of $5 \mathrm{~g} /$ pot as well as:

Compost 1: Rice straw + okara + rock phosphate, $\mathrm{C} / \mathrm{N}$ ratio 33:44,

Compost 2: Rice straw + okara + rock phosphate + composite inoculums at the rate of $2 \mathrm{~g} / \mathrm{pot}, \mathrm{C} / \mathrm{N}$ ratio 32:13,

Compost 3: Rice straw + okara + rock phosphate + composite inoculums + buffalo manure, $\mathrm{C} / \mathrm{N}$ ratio 32.73 , Nemacur $10 \% \mathrm{G}$ at the rate of $2 \mathrm{~g} /$ pot.

Materials were incorporated with the pot soil around the plant. Each treatment was replicated four times. One week later, each pot was inoculated with 3000 freshly hatched juveniles $\left(\mathrm{J}_{2}\right)$ of Meloidogyne incognita by pitting the nematode water suspension into 4 holes around root system and immediately covered with sand. Check pots were inoculated with nematode and kept free from any treatment material as well as non inoculated healthy plants. All treatments were arranged in a randomized design on a greenhouse clean bench at $32 \pm 5^{\circ} \mathrm{C}$ and watered daily for 45 days. Then, plants were lifted out and data on plant growth were recorded and nematode population in soil and roots was counted.

\section{Nematode extraction and enumeration}

\section{Soil population}

Each pot was soaked in a plastic bucket filled with water until the root-system could be separated. Each root system was weighed and stored in 5\% formaldehyde in plastic jars. The soil suspension was quite stirred, and then poured through a series of sieves of $60,200,325$ mesh. The bottom sieve (325) was backwashed into a $250 \mathrm{ml}$ plastic beaker. The suspension was then poured into a modified Barmann set and collected after 48 hours. Hawksley counting slide was used to calculate the number of $\mathrm{J}_{2}$ in one milliliter of the clean suspension and then referred to whole volume.

\section{Root population}

Roots were stained using acid fuchsine powder. $5.0 \mathrm{~g}$ of the stain were added to one liter of water, stirred and heated to boiling for about one minute. The root was then immersed in the stain for one minute, then removed and soaked in tap water to get rid of the excess stains. Developmental stages, mature females and eggmasses were counted under a stereomicroscope using two fine dissecting needles.

\section{Plant chemical analysis}

Subsamples of fresh shoot and root of each treatment were chemically analyzed as follows:

\section{Lipid peroxidation determination (MDA contents)}

The lipid peroxidation products were estimated by the formation of thiobarbaturic acid reactive substances 
134

(TBARS) and quantified in terms of malondialdhyde (MDA) as described by Haraguchi et al. (1995). Two hundred $\mathrm{mg}$ samples were homogenized in $2 \mathrm{ml}$ of $0.1 \%$ trichloroacetic acid (TCA) (w/v), followed by centrifugation at $12,000 \times g$ for $20 \mathrm{~min}$. The supernatant $(1 \mathrm{ml})$ obtained was mixed with an equal volume of TCA (10\%) containing $0.5 \%$ TBARS or no TBARS (w/v) as blank, and heated at $95^{\circ} \mathrm{C}$ for $30 \mathrm{~min}$ and then cooled in ice. The reaction product was centrifuged at $12,000 \times g$ for $15 \mathrm{~min}$ and the supernatant absorbance was measured at 532 and $600 \mathrm{~nm}$. After subtracting the non-specific absorbance $(600 \mathrm{~nm})$, the MDA concentration was determined by its molar extinction coefficient of $155 \mathrm{mM}^{-1} \mathrm{~cm}^{-1}$ and the results are expressed as $\mu \mathrm{mol} / \mathrm{g}$ f.w.

\section{Hydrogen peroxide determination}

Hydrogen peroxide was measured by the method described by Capaldi and Taylor (1983) at the rate of $2 \mathrm{~g} /$ pot with a slight modification. The samples were ground in $5 \%$ TCA ( $2.5 \mathrm{ml}$ per $0.5 \mathrm{~g}$ fresh shoots or roots) with 50 $\mathrm{mg}$ active charcoal at $0^{\circ} \mathrm{C}$, and centrifuged for $10 \mathrm{~min}$ at $15,000 \times g$ at $4^{\circ} \mathrm{C}$. Supernatant was collected, neutralized with $4 \mathrm{~N} \mathrm{KOH}$ to $\mathrm{pH} 3.6$ and used for $\mathrm{H}_{2} \mathrm{O}_{2}$ assay. The reaction mixture contained $200 \mu \mathrm{l}$ of leaf extract, $100 \mu \mathrm{l}$ of 3.4 mM 3-methylbenzothiazoline hydrazone (MBTH). The reaction was initiated by adding $500 \mu$ of horseradish peroxidase solution ( $90 \mathrm{U}$ per $100 \mathrm{ml}$ ) in $0.2 \mathrm{M}$ sodium acetate ( $\mathrm{pH}$ 3.6). Two minutes later $1400 \mu \mathrm{l}$ of $1 \mathrm{~N} \mathrm{HCl}$ was added. Absorbance was recorded at $630 \mathrm{~nm}$ after 15 $\min$.

\section{Total glutathione determination}

The level of total acid-soluble SH (sulphydryl) compound (glutathione GSH) was determined with Ellman's reagent according to De Vos et al. (1992). Samples (0.5 g) were homogenized in 6\% m-phosphoric acid $(\mathrm{pH} 2.8)$ containing $1 \mathrm{mM}$ EDTA. The buffer was mixed with 630 $\mu \mathrm{l}$ of $0.5 \mathrm{M} \mathrm{K}_{2} \mathrm{HPO}_{4}$ and $25 \mu \mathrm{l}$ of mM 5, 5'-dithiobis (2-nitrobenzoic acid) ( $\mathrm{pH}$ 7.0). The absorbance was recorded at $412 \mathrm{~nm}$ after $2 \mathrm{~min}$. The GSH concentration was determined from a standard curve. Results were expressed in terms of $\mu \mathrm{mol} / \mathrm{g}$ f.w.

\section{Ascorbic acid determination}

Levels of AsA were determined as per the methods described by Singh et al. (2006) with slight modifications. Briefly, fresh shoots or roots sample of a known weight $(1 \mathrm{~g})$ was extracted with $3 \mathrm{ml}$ of $5 \%(\mathrm{w} / \mathrm{v})$ trichloroacetic acid (TCA) and centrifuged at $18,000 \times g$ for $15 \mathrm{~min}$. AsA was determined in a reaction mixture consisting of $0.2 \mathrm{ml}$ of supernatant, $0.5 \mathrm{ml}$ of $150 \mathrm{mM}$ phosphate buffer $(\mathrm{pH}$ 7.4, containing $5 \mathrm{mM}$ EDTA) and $0.2 \mathrm{ml}$ of deionized water. Color was developed in reaction mixtures with the addition of $0.4 \mathrm{ml}$ of $10 \%(\mathrm{w} / \mathrm{v})$ TCA, $0.4 \mathrm{ml}$ of $44 \%(\mathrm{v} / \mathrm{v})$ phosphoric acid, $0.4 \mathrm{ml}$ of $\alpha, \alpha$ - dipyridyl in $70 \%(\mathrm{v} / \mathrm{v})$ ethanol and $0.2 \mathrm{ml}$ of $3 \%(\mathrm{w} / \mathrm{v}) \mathrm{FeCl}_{3}$. The reaction mixtures were incubated at $40^{\circ} \mathrm{C}$ for $40 \mathrm{~min}$. and the absorbance was read at $532 \mathrm{~nm}$.

\section{Soluble protein determination}

Soluble proteins were measured by the Bio-Rad micro assay modification of the Bradford (1976) procedure using crystalline bovine serum albumin as a reference.

\section{Determination of antioxidant enzymes}

\section{Preparation of enzyme extracts}

Samples of $0.5 \mathrm{~g}$ was homogenized in $5 \mathrm{ml}$ phosphate buffer ( $50 \mathrm{mM}, \mathrm{pH} 7.0$ ) containing $0.1 \mathrm{~N} \mathrm{NaCl}, 1 \% \mathrm{PVP}$ M.W. $40,000,1 \mathrm{mM}$ ascorbate at $4^{\circ} \mathrm{C}$. After centrifugation (at $15,000 \times \mathrm{g}$ for $15 \mathrm{~min}$ ) the supernatant was collected and used as enzyme extract.

\section{Superoxide dismutase assay}

The activity of SOD was assayed by measuring its ability to inhibit the photochemical reduction of NBT using the method of (Beauchamp and Fridovich, 1971). The 3 $\mathrm{ml}$ reaction mixture contained $50 \mathrm{mM}$ phosphate buffer $\mathrm{pH} 7.8,13 \mathrm{mM}$ methionine, $75 \mu \mathrm{M}$ NBT, $2 \mu \mathrm{M}$ riboflavin, $1.0 \mathrm{mM}$ EDTA and $20 \mu \mathrm{l}$ enzyme extract. Riboflavin was added last and the reaction was initiated by placing the tubes $30 \mathrm{~cm}$ below $15 \mathrm{~W}$ fluorescent lamps. The reaction was started by switching on the light and was allowed to run for $10 \mathrm{~min}$. Switching off the light stopped the reaction and the tubes were covered with black cloth. Nonilluminated tubes served as control. The absorbance at 560 $\mathrm{nm}$ was read. One unit of SOD is the amount of extracts that gives $50 \%$ inhibition the rate of NBT reduction.

\section{Ascorbate peroxidase assay}

Ascorbate peroxidase activity (APOX; E.C. 1.11. 1. 11) was estimated according to the method of Nakano and Asada (1981). Enzyme activity was determined by the decrease in absorbance of ascorbate at $290 \mathrm{~nm}$. The reaction mixture consisted of enzymatic extract, $50 \mathrm{mM}$ sodium phosphate buffer (cold), pH 7, $0.5 \mathrm{mM}$ ascorbate, $0.5 \mathrm{mM}$ $\mathrm{H}_{2} \mathrm{O}_{2}$ and $0.1 \mathrm{mM}$ EDTA, in a $0.3 \mathrm{ml}$ final volume. The reaction started after the hydrogen peroxide addition. The molar extinction coefficient $2.8 \mathrm{mM}^{-1} \mathrm{~cm}^{-1}$ was used to calculate ascorbate peroxidase activity. Enzyme activity was expressed as unit's $\mathrm{mg}^{-1}$ protein. One unit of enzyme was the amount necessary to decompose $1 \mu \mathrm{mol}$ of substrate per minute at $25^{\circ} \mathrm{C}$.

\section{Catalase activity assay}

Catalase activity (CAT; EC 1.11.1.6) was determined by consumption of $\mathrm{H}_{2} \mathrm{O}_{2}$ using the method of Dhindsa et al. (1981). The reaction mixture $(3 \mathrm{ml})$ contained $50 \mathrm{mM}$ potassium phosphate buffer $\mathrm{pH} 7.0,15 \mathrm{mM} \mathrm{H}_{2} \mathrm{O}_{2}$ and 50 $\mathrm{ml}$ enzyme extract. The reaction was initiated by adding the $\mathrm{H}_{2} \mathrm{O}_{2}$. The consumption of $\mathrm{H}_{2} \mathrm{O}_{2}$ was monitored spectrophotometrically at $240 \mathrm{~nm}\left(\Sigma^{2}=39.4 \mathrm{mM}^{-1} \mathrm{~cm}^{-1}\right)$ for 3 min. 
Glutathione-S-transferase assay

Glutathione-S-transferase activity was measured according to the method of Mannervik and Guthenberg (1981) by following the changes in the absorbance at 340 $\mathrm{nm}$ in a mixture containing $0.17 \mathrm{mM}$ sodium phosphate buffer, $\mathrm{pH}$ 6.5, $1 \mathrm{mM}$ GSH, $1 \mathrm{mM}$ 1-chloro-2,4-dinitrobenzene $(\mathrm{CDNB})$ in ethanol and enzyme extract. EU $=$ the amount of enzyme that catalyses the formation of 1 $\mu \mathrm{mol}$ of S-2, 4- dinitrophenylglutathione $\mathrm{min}^{-1}$.

\section{Phenylalanine ammonia lyase assay}

Phenylalanine ammonia-lyase activity (PAL; E.C. 4.3.1.5) was determined based on the rate of cinnamic acid production as described by Ochoa-Alejo and GomezPeralta (1993). Briefly, $1 \mathrm{ml}$ of $50 \mathrm{mM}$ Tris- $\mathrm{HCl}$ buffer $\mathrm{pH}$ 8.8 containing $15 \mathrm{mM}$ of $\beta$-mercaptoethanol, $0.5 \mathrm{ml}$ of 10 $\mathrm{mM} \mathrm{L}$-phenylalanine, $0.4 \mathrm{ml}$ of double distilled water and $0.1 \mathrm{ml}$ of enzyme extract were incubated at $37^{\circ} \mathrm{C}$ for $1 \mathrm{hr}$. The reaction was terminated by addition of $0.5 \mathrm{ml}$ of $6 \mathrm{M}$ $\mathrm{HCl}$ and the product was extracted with $15 \mathrm{ml}$ ethyl acetate, followed by evaporation to remove the extracting solvent. The solid residue was suspended in $3 \mathrm{ml}$ of $0.05 \mathrm{M}$ $\mathrm{NaOH}$ and the cinnamic acid concentration wherein was quantified with the absorbance $290 \mathrm{~nm}$. One unit of PAL activity is equal to $1 \mu \mathrm{mol}$ of cinnamic acid produced per min.

\section{Statistical analysis}

All experimental results were expressed as means \pm S.D. Analysis of variance was performed by ANOVA

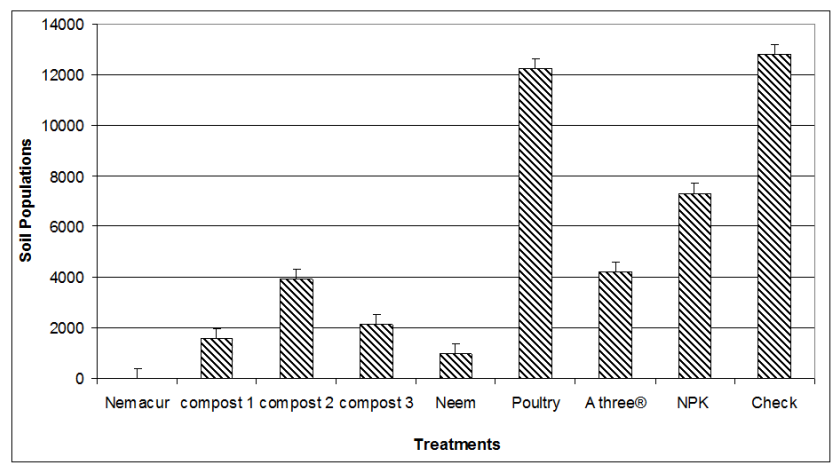

Fig. 1. Soil population / pot as influenced by some fertilizers

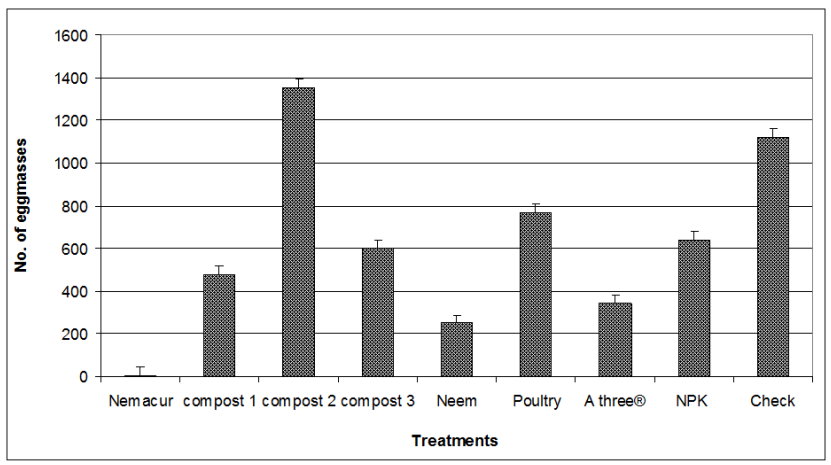

Fig. 3. Eggmasses / root as influenced by some fertilizers procedures. The results with $p<0.05$ were regarded to be statistically significant. Data were statistically analyzed MSTAT-C statistical package (Michigan State University, 1989).

\section{Results}

\section{Nematode development and reproduction}

Data presented in Fig. 1-5 reveal that all tested organic amendments applied singly at the $5.0 \mathrm{~g} /$ pot remarkably impaired gall formation, juveniles recovered from the soil, the numbers of the developmental stages, eggmasses, size of nematode population, nematode build up and egg production as compared with the untreated check with few exceptions. Although compost 2 increased significantly the number of eggmasses/g. root and the number of galls/ root, it decreased nematode fecundity (eggs/eggmass). Poultry increased all nematode criteria as compared with other treatments. Differences in nematode reductions were obvious among treatments. Neem, compost 1 and compost 3 at higher doses, in that order, gave the best results. Concerning the inorganic fertilizer, it is interesting to note that the commercial product (A three ${ }^{\circ}$ ) was more effective in suppressing the nematode developmental stages, eggmasses and gall formation than the prepared NPK. The utmost reductions in over all values of nematode criteria were achieved by Nemacur $10 \%$ G. The nematicide protected the roots from nematode invasion which resulted in sharp reduction in the number of galls, eggmasses, and fecundity and smashing the nematode build up.

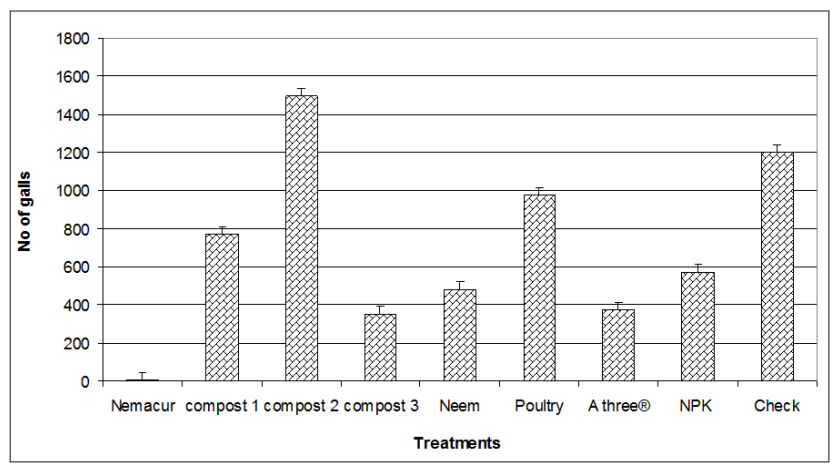

Fig. 2. No. of galls / root as influenced by some fertilizers

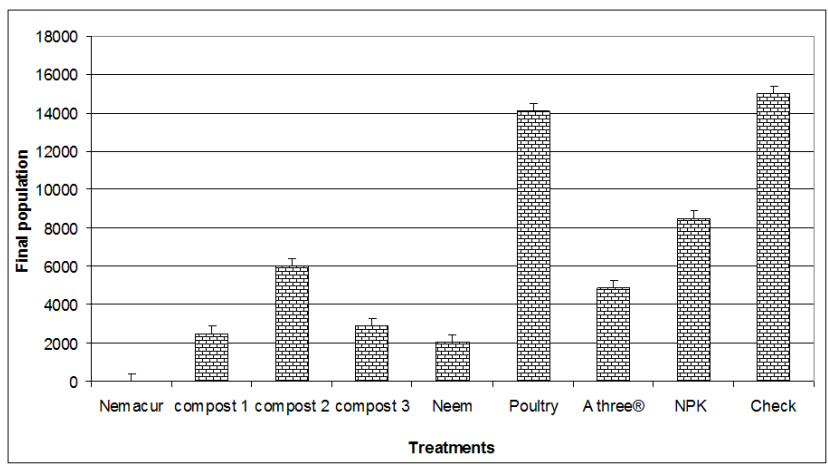

Fig. 4. Final population / pot as influenced by some fertilizers 
136

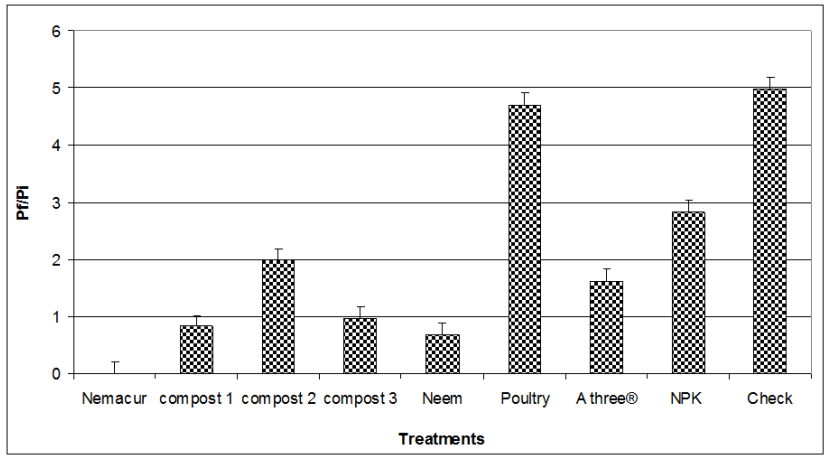

Fig. 5. Build up of Meloidogyne incognita as influenced by some fertilizers

Content of tomato oxidative burst and antioxidant substances as well as enzyme activities

Oxidative burst lipid peroxidation (MDA), hydrogen peroxide $\left(\mathrm{H}_{2} \mathrm{O}_{2}\right)$ concentration; antioxidant substance glutathione $(\mathrm{GSH})$ and ascorbic acid content; antioxidant enzyme activities, superoxide dismutase (SOD), ascorbate peroxidase (APX) and catalase (CAT), glutathione$S$-transferase (GST) and phenylalanine ammonia lyase (PAL) were determined in shoots and roots of healthy and infected tomato plants and those treated with organic and inorganic fertilizers. Results in Tab. 1 and 2 manifested that infection of tomato with the root-knot nematode, $M$. incognita significantly escalated the contents of shoots and roots of lipid peroxidation (MDA) as compared to the untreated healthy plants. Nematodes increased MDA by $705,482 \%$ in shoots and roots, respectively. Application of nemacur, in spite of reducing nematode population, did not succeed in reducing plant contents of peroxidases. The nematicide raised MDA by 610 and $428 \%$ in shoots and roots of infected plants, in that order. Treating the infected tomato with composts, neem, poultry droppings, and inorganic fertilizers did a very good job in reducing the contents of MDA in infected plants. Compost 3, neem and poultry dropping, sequentially achieved the best results whereas MDA contents in such treatments did not vary significantly with the untreated healthy plants. Compost 1,2; compound NPK and A three came statistically in the second group. On the whole, roots of healthy or infected tomato had slightly higher content of MDA than shoots.

Virtually, similar results were obtained with the hydrogen peroxide $\left(\mathrm{H}_{2} \mathrm{O}_{2}\right)$ whereas shoots and roots of healthy plants had the lowest significant contents. Nematode infection significantly augmented $\mathrm{H}_{2} \mathrm{O}_{2}$ values. The percentage of increase reached as high as $1024,887 \%$ in shoots and roots, respectively. All treatments including nemacur significantly reduced shoot and roots contents of $\mathrm{H}_{2} \mathrm{O}_{2}$. Also, compost 3 was paramount in reducing $\mathrm{H}_{2} \mathrm{O}_{2}$ in infected plants followed by neem and poultry droppings to be nearly to those in the healthy plants but with significant differences among treatments and between treatments and the check (Tab. 1). Compost 1,2, NPK came in the second category with significant differences between treatments. It is also observed that root content of $\mathrm{H}_{2} \mathrm{O}_{2}$ in healthy and infected plants are higher than shoot contents. Concerning the antioxidant substances, data in Tab. 2 speculated that the levels of the non enzymatic glutathione (GSH) and ascorbic acid in the healthy plants were as low as $3.35,4.20 \mu \mathrm{mol} / \mathrm{g}$ fresh weight and $8.06,10.11 \mathrm{mg} / \mathrm{g}$ fresh weight of shoots and roots, consecutively. Nematode infection resulted in a slight but significant increase in both glutathione (by 29.3, 25.7\%) and ascorbic acid (by $14.8,6.9 \%)$ in shoots and roots, in sequence.

All treatments significantly increased the antioxidant substances comparing to healthy and infected untreated tomato plants. Nemacur increased percentages of glutathione by 56.1 and $51.2 \%$ and ascorbic acid by 28.7 and $22.6 \%$ in shoots and roots, in that order. However, other treatments accomplished higher percentages of increment comparing to nemacur and infected plants. It is evident that compost 3 is the best treatment that helps plants to overcome nematode injury by increasing the antioxidant substances. Treating infected plants with compost 3 boosted GSH levels to the highest significant values in both shoots and roots $(23.75,26.76 \mu \mathrm{mol} / \mathrm{g}$ fresh weight, respectively) Tab. 1. Content of lipid peroxidation (MDA) and hydrogen peroxide $\left(\mathrm{H}_{2} \mathrm{O}_{2}\right)$ in shoots and roots of tomato seedlings as affected by nematode infection and application of nemacur, organic and inorganic fertilizers

\begin{tabular}{|c|c|c|c|c|}
\hline \multirow{2}{*}{ Treatments } & \multicolumn{2}{|c|}{ MDA ( $\mu \mathrm{mol} / \mathrm{g}$ f.w. $)$} & \multicolumn{2}{|c|}{$\mathrm{H}_{2} \mathrm{O}_{2}(\mu \mathrm{mol} / \mathrm{g}$ f.w. $)$} \\
\hline & Shoots & Roots & Shoots & Roots \\
\hline Healthy & $2.32 \pm 0.23^{\mathrm{d}}$ & $3.55 \pm 0.24^{\mathrm{i}}$ & $4.84 \pm 0.32^{j}$ & $6.97 \pm 0.26^{j}$ \\
\hline Nematode only & $18.7 \pm 0.37^{\mathrm{a}}$ & $20.7 \pm 0.40^{\mathrm{a}}$ & $54.4 \pm 1.12^{\mathrm{a}}$ & $68.8 \pm 0.28^{a}$ \\
\hline Nemacur & $16.5 \pm 0.64^{\mathrm{a}}$ & $18.8 \pm 0.24^{\mathrm{b}}$ & $50.2 \pm 1.53^{\mathrm{b}}$ & $60.0 \pm 0.84^{\mathrm{b}}$ \\
\hline Compost 1 & $6.57 \pm 0.33^{b c}$ & $8.20 \pm 0.39^{c}$ & $22.7 \pm 0.56^{\mathrm{f}}$ & $23.4 \pm 0.60^{f}$ \\
\hline Compost 2 & $7.43 \pm 0.41^{b}$ & $9.60 \pm 0.37^{\mathrm{d}}$ & $27.4 \pm 0.55^{\mathrm{c}}$ & $27.5 \pm 0.79^{\mathrm{c}}$ \\
\hline Compost 3 & $3.13 \pm 0.21^{d}$ & $4.37 \pm 0.26^{\mathrm{h}}$ & $7.29 \pm 0.44^{\mathrm{i}}$ & $9.82 \pm 0.45^{\mathrm{i}}$ \\
\hline Neem & $3.75 \pm 0.19^{\mathrm{cd}}$ & $5.27 \pm 0.30^{g}$ & $9.57 \pm 0.28^{\mathrm{h}}$ & $12.4 \pm 0.47^{\mathrm{h}}$ \\
\hline Poultry & $4.55 \pm 0.32^{\mathrm{cd}}$ & $6.54 \pm 0.34^{f}$ & $15.6 \pm 1.02^{\mathrm{g}}$ & $18.8 \pm 1.18^{g}$ \\
\hline A three $e^{\circ}$ & $8.64 \pm 0.31^{b}$ & $10.1 \pm 0.36^{\mathrm{d}}$ & $30.6 \pm 0.99^{d}$ & $35.8 \pm 1.28^{\mathrm{d}}$ \\
\hline NPK & $7.51 \pm 4.89^{b}$ & $12.5 \pm 0.38^{c}$ & $35.7 \pm 0.77^{c}$ & $40.9 \pm 1.17^{c}$ \\
\hline LSD 5\% & 0.923 & 0.704 & 1.322 & 1.502 \\
\hline
\end{tabular}

*Values are mean of three replicates $\pm S D$, number in the same column followed by the same letter are not significantly different at $p<0.05$ 
Tab. 2. Content of glutathione (GSH) and ascorbic acid in shoots and roots of tomato as affected by nematode infection and application of nemacur, organic and inorganic fertilizers

\begin{tabular}{ccccc}
\hline \multirow{2}{*}{ Treatments } & \multicolumn{2}{c}{ GSH $(\mu \mathrm{mol} / \mathrm{g}$ f.w. $)$} & \multicolumn{2}{c}{ Ascorbic acid $(\mathrm{mg} / \mathrm{g}$ f.w. $)$} \\
\cline { 2 - 5 } & Shoots & Roots & $8.06 \pm 0.18^{\mathrm{j}}$ & $10.1 \pm 0.22^{\mathrm{i}}$ \\
\hline Healthy & $3.35 \pm 0.21^{\mathrm{i}}$ & $4.20 \pm 0.17^{\mathrm{j}}$ & $9.25 \pm 0.31^{\mathrm{i}}$ & $10.8 \pm 0.18^{\mathrm{i}}$ \\
\hline Nematode only & $4.33 \pm 0.29^{\mathrm{h}}$ & $5.28 \pm 0.14^{\mathrm{i}}$ & $10.4 \pm 0.28^{\mathrm{h}}$ & $12.4 \pm 0.39^{\mathrm{h}}$ \\
\hline Nemacur & $5.23 \pm 0.32^{\mathrm{h}}$ & $6.35 \pm 0.28^{\mathrm{h}}$ & $23.4 \pm 0.58^{\mathrm{d}}$ & $28.5 \pm 0.49^{\mathrm{d}}$ \\
\hline Compost 1 & $14.8 \pm 0.66^{\mathrm{d}}$ & $17.1 \pm 0.43^{\mathrm{d}}$ & $19.2 \pm 0.62^{\mathrm{c}}$ & $24.1 \pm 0.71^{\mathrm{c}}$ \\
\hline Compost 2 & $12.8 \pm 0.49^{\mathrm{c}}$ & $14.6 \pm 0.36^{\mathrm{c}}$ & $36.6 \pm 0.61^{\mathrm{a}}$ & $40.8 \pm 0.66^{\mathrm{a}}$ \\
\hline Compost 3 & $23.8 \pm 1.10^{\mathrm{a}}$ & $26.8 \pm 0.53^{\mathrm{a}}$ & $32.9 \pm 0.78^{\mathrm{b}}$ & $37.7 \pm 0.36^{\mathrm{b}}$ \\
\hline Neem & $20.6 \pm 0.45^{\mathrm{b}}$ & $25.3 \pm 0.46^{\mathrm{b}}$ & $27.8 \pm 0.33^{\mathrm{c}}$ & $33.3 \pm 0.49^{\mathrm{c}}$ \\
\hline Poultry & $17.4 \pm 0.47^{\mathrm{c}}$ & $21.5 \pm 0.65^{\mathrm{c}}$ & $15.8 \pm 0.46^{\mathrm{f}}$ & $19.3 \pm 0.53^{\mathrm{f}}$ \\
\hline A three & $10.6 \pm 0.31^{\mathrm{f}}$ & $11.3 \pm 0.52^{\mathrm{f}}$ & $12.9 \pm 0.43^{\mathrm{g}}$ & $15.7 \pm 0.37^{\mathrm{g}}$ \\
\hline NPK & $7.55 \pm 0.51^{\mathrm{g}}$ & $8.39 \pm 0.39^{\mathrm{g}}$ & 1.452 & 1.13 \\
\hline LSD 5\% & 1.023 & 1.164 &
\end{tabular}

*Values are mean of three replicates $\pm S D$, number in the same column followed by the same letter are not significantly different at $p<0.05$

achieving an increase percentages of $609,537 \%$. Neem came statistically after, then poultry and compos 1 , while NPK gave the least value $(7.55 \mu \mathrm{mol} / \mathrm{g} \mathrm{FW})$ and the least percentage of increase $(125.4 \%)$ in roots of infected tomato. Similar results were obtained with ascorbic acid contents in shoots and roots (Tab. 2).

Regarding the antioxidant enzymes activity, it is clear from Tab. 3 that the activity levels of superoxide dismutase (SOD), ascorbate peroxidase (APX) and catalase (CAT) in healthy plants were 66.6, 15.7, 7.35 and 42.7, 11.6 and $5.9 \mathrm{unit} / \mathrm{mg}$ protein $/ \mathrm{min}$ in shoots and roots respectively. Nematode infection significantly increased such enzymes activities with percentages of 12.0, 10.2, 18.2 and 17.1, 15.5 and $28.8 \%$, in that order. Greater increasing rates of the antioxidant enzyme activities were observed in all treatments. The lowest rate was implemented by the nematicide, nemacur; while the highest rate was achieved by compost 3 . The results emphasized the role of organic materials in improving plant growth and inducing resistance against root-knot nematode which resulted in protecting plants from nematode infection, followed by the inorganic fertilizers, however, the nematicide (Nemacur $10 \% \mathrm{G}$ ) induced weak effect. Its role in protecting plants due mainly to its direct effect on nematodes.

Glutathione-S-transferase (GST) activity in shoots and roots of healthy tomato were 4.76 and $5.35 \mathrm{unit} / \mathrm{mg}$ protein $/ \mathrm{min}$, respectively (Tab. 4). Tremendous increase in GST was provoked by M. incognita infection (878.6, $844.1 \%$ ) in shoots and roots, sequentially. Nemacur application boosted GST over that in healthy or infected plants. On the other hand, Plants treated with organic matter showed the lowest activity of glutathione-S-transferase. Compost 3 lowered GST activity to levels near that in healthy plants, followed by neem and poultry droppings. The compound NPK gave the worst results.

Phenylalanine ammonia lyase (PAL) was at its lowest activity in shoots and roots of healthy plants. Slight and significant increase was observed in shoots and roots of infected untreated plants or those infected and treated with nemacur (Tab. 4). Enormous increase in PAL activity was Tab. 3. Superoxide dismutase (SOD), ascorbate peroxidase (APX) and catalase (CAT) activities in tomato shoots and roots as affected by nematode infection and application of nemacur, organic and inorganic fertilizers

\begin{tabular}{|c|c|c|c|c|c|c|}
\hline \multirow[t]{2}{*}{ Treatments } & \multicolumn{2}{|c|}{$\begin{array}{c}\text { SOD activity } \\
\text { (Unit/mg protein/min) }\end{array}$} & \multicolumn{2}{|c|}{$\begin{array}{c}\text { APX activity } \\
\text { (Unit/mg protein/min) }\end{array}$} & \multicolumn{2}{|c|}{$\begin{array}{c}\text { CAT activity } \\
(\text { Unit } / \mathrm{mg} \text { protein } / \mathrm{min})\end{array}$} \\
\hline & Shoots & Roots & Shoots & Roots & Shoots & Roots \\
\hline Healthy & $66.6 \pm 0.52^{j}$ & $42.7 \pm 0.53^{j}$ & $15.7 \pm 0.24^{j}$ & $11.6 \pm 0.26^{j}$ & $7.35 \pm 0.28^{j}$ & $5.9 \pm 0.24^{j}$ \\
\hline Nematode only & $74.6 \pm 0.59^{i}$ & $50.0 \pm 0.58^{\mathrm{i}}$ & $17.3 \pm 0.30^{i}$ & $13.4 \pm 0.31^{\mathrm{i}}$ & $8.69 \pm 0.30^{\mathrm{i}}$ & $7.6 \pm 0.24^{i}$ \\
\hline Nemacur & $80.8 \pm 0.46^{\mathrm{h}}$ & $60.1 \pm 0.69^{\mathrm{h}}$ & $20.4 \pm 0.29^{h}$ & $15.7 \pm 0.26^{\mathrm{h}}$ & $10.4 \pm 0.34^{\mathrm{h}}$ & $9.8 \pm 0.36^{\mathrm{h}}$ \\
\hline Compost1 & $133.4 \pm 0.77^{\mathrm{d}}$ & $107.8 \pm 0.71^{\mathrm{d}}$ & $50.9 \pm 0.39^{d}$ & $44.5 \pm 0.39^{d}$ & $67.7 \pm 0.36^{\mathrm{d}}$ & $55.5 \pm 0.41^{\mathrm{d}}$ \\
\hline Compost2 & $126.7 \pm 0.71^{\mathrm{c}}$ & $100.3 \pm 0.63^{\mathrm{c}}$ & $43.7 \pm 0.39^{c}$ & $38.8 \pm 0.35^{\mathrm{c}}$ & $60.4 \pm 0.33^{c}$ & $50.8 \pm 0.37^{c}$ \\
\hline Compost 3 & $158.9 \pm 0.52^{\mathrm{a}}$ & $136.7 \pm 0.42^{\mathrm{a}}$ & $67.9 \pm 0.59^{\mathrm{a}}$ & $62.6 \pm 0.47^{\mathrm{a}}$ & $90.2 \pm 0.58^{\mathrm{a}}$ & $75.6 \pm 0.35^{\circ}$ \\
\hline Neem & $152.9 \pm 0.57^{b}$ & $129.9 \pm 0.59^{b}$ & $63.5 \pm 0.44^{\mathrm{b}}$ & $58.5 \pm 0.41^{b}$ & $80.6 \pm 0.46^{b}$ & $67.7 \pm 0.39^{b}$ \\
\hline Poultry & $145.1 \pm 0.48^{c}$ & $112.0 \pm 0.41^{\mathrm{c}}$ & $56.5 \pm 0.49^{c}$ & $50.6 \pm 0.37^{c}$ & $75.8 \pm 0.43^{c}$ & $60.6 \pm 0.37^{c}$ \\
\hline A three" & $118.0 \pm 0.70^{\mathrm{f}}$ & $82.9 \pm 0.54^{\mathrm{f}}$ & $37.7 \pm 0.28^{f}$ & $30.5 \pm 0.27^{\mathrm{f}}$ & $51.4 \pm 0.42^{f}$ & $43.6 \pm 0.31^{\mathrm{f}}$ \\
\hline NPK & $106.2 \pm 0.73^{g}$ & $70.1 \pm 0.68^{g}$ & $29.5 \pm 0.34^{g}$ & $25.4 \pm 0.42^{g}$ & $45.0 \pm 0.33^{g}$ & $28.7 \pm 0.29^{g}$ \\
\hline LSD 5\% & 1.452 & 1.251 & 1.015 & 1.136 & 1.324 & 1.077 \\
\hline
\end{tabular}

*Values are mean of three replicates \pm SD, number in the same column followed by the same letter are not significantly different at $p<0.05$ 
Tab. 4. Activity of glutathione-S-transferase (GST) and phenylalanine ammonia lyase (PAL) in tomato shoots and roots as affected by nematode infection and application of nemacur, organic and inorganic fertilizers

\begin{tabular}{ccccc}
\hline \multirow{2}{*}{ Treatments } & \multicolumn{2}{c}{ GST (Unit/mg protein/min) } & \multicolumn{2}{c}{ PAL (Unit/mg protein/min) } \\
\cline { 2 - 5 } & Shoots & Roots & Shoots & Roots \\
\hline Healthy & $4.76 \pm 0.19^{\mathrm{j}}$ & $5.35 \pm 0.14^{\mathrm{j}}$ & $4.62 \pm 0.25^{\mathrm{j}}$ & $6.42 \pm 0.24^{\mathrm{j}}$ \\
\hline Nematode only & $46.6 \pm 0.36^{\mathrm{b}}$ & $50.5 \pm 0.35^{\mathrm{b}}$ & $6.24 \pm 0.19^{\mathrm{i}}$ & $9.38 \pm 0.21^{\mathrm{i}}$ \\
\hline Nemacur & $50.3 \pm 0.27^{\mathrm{a}}$ & $56.6 \pm 0.37^{\mathrm{a}}$ & $8.52 \pm 0.31^{\mathrm{h}}$ & $11.4 \pm 0.23^{\mathrm{h}}$ \\
Compost 1 & $18.8 \pm 0.29^{\mathrm{f}}$ & $23.5 \pm 0.33^{\mathrm{f}}$ & $38.5 \pm 0.31^{\mathrm{d}}$ & $41.2 \pm 0.38^{\mathrm{d}}$ \\
\hline Compost 2 & $21.9 \pm 0.33^{\mathrm{c}}$ & $26.0 \pm 0.34^{\mathrm{c}}$ & $33.6 \pm 0.31^{\mathrm{c}}$ & $35.6 \pm 0.33^{\mathrm{c}}$ \\
\hline Compost 3 & $6.68 \pm 0.32^{\mathrm{i}}$ & $8.33 \pm 0.28^{\mathrm{i}}$ & $59.9 \pm 0.43^{\mathrm{a}}$ & $64.8 \pm 0.42^{\mathrm{a}}$ \\
\hline Neem & $9.66 \pm 0.38^{\mathrm{h}}$ & $12.4 \pm 0.24^{\mathrm{h}}$ & $53.5 \pm 0.46^{\mathrm{b}}$ & $58.6 \pm 0.32^{\mathrm{b}}$ \\
Poultry & $15.5 \pm 0.26^{\mathrm{g}}$ & $17.5 \pm 0.29^{\mathrm{g}}$ & $49.0 \pm 0.31^{\mathrm{c}}$ & $50.5 \pm 0.36^{\mathrm{c}}$ \\
\hline A three & $28.7 \pm 0.33^{\mathrm{d}}$ & $31.4 \pm 0.32^{\mathrm{d}}$ & $26.4 \pm 0.36^{\mathrm{f}}$ & $29.3 \pm 0.38^{\mathrm{f}}$ \\
NPK & $31.6 \pm 0.36^{\mathrm{c}}$ & $39.1 \pm 0.40^{\mathrm{c}}$ & $19.5 \pm 0.28^{\mathrm{g}}$ & $22.4 \pm 0.52^{\mathrm{g}}$ \\
\hline LSD 5\% & 1.076 & 1.224 & 1.082 & 1.154 \\
\hline
\end{tabular}

*Values are mean of three replicates $\pm S \mathrm{D}$, number in the same column followed by the same letter are not significantly different at $p<0.05$

observed in shoots and roots of plants treated with organic fertilizers. In plants treated with compost 3, PAL activity was increased in shoots and roots by 1196.1, 909.7\% over the healthy plants followed by neem and poultry droppings. Compost 1 , compost 2 and the $\mathrm{A}$ three in that order came after, NPK as well, ranked statistically in third group.

\section{Discussion}

Although a root-knot nematode infecting a root causes little damage as it migrate between the cells, ROS overproduction can be detected as early as $J_{2}$ penetration. In general, the initial reaction of the susceptible cultivars is similar to that of resistant host and may be result from nematode secretions into plant tissues during migration (Davis et al., 2000; Huang et al., 2004). It is suggested that, in tomato plants, higher generation of ROS, especially $\mathrm{H}_{2} \mathrm{O}_{2}$ as a result of pathogens infection appears to be an important element of disease-resistant mechanisms and also, induced lipid peroxidation may be one of the mechanisms accounting for cell death (Borden and Higgins, 2002; Mellersh et al., 2002). Tomato plants reacted to root-knot nematodes by mounting defense responses. The timing and extent of the reaction differed, providing some clues as to which of these responses may be effective in defense. In the initial steps of the interaction between the plant and nematode, $\mathrm{J}_{2}$ penetration into the root tissues was equally low in compatible and incompatible situations. In the later stages, nematode penetration was blocked in the incompatible interaction only, while $\mathrm{J}_{2}$ can invade the roots to develop their feeding sites in the compatible interactions. At that time, a second oxidative burst associated with $\mathrm{HR}$ was observed in incompatible interactions. In the compatible tomato-nematode relationships, $\mathrm{ROS}$ and $\mathrm{H}_{2} \mathrm{O}_{2}$ generation was seen at the time of pest invasion (Melillo et al., 2006). High concentrations of hydrogen peroxide, the essential precursor of hydroxyl radicals, appear to play a key role in the oxidative events during early stages of infection.

It is well known that $\mathrm{H}_{2} \mathrm{O}_{2}$ acts as signaling molecule that triggers gene activation, or as cofactor in a process that requires new gene expression for both localized cell death and inductions of defense genes in adjacent cells (Mellersh et al., 2002). Excess of the $\mathrm{H}_{2} \mathrm{O}_{2}$ found to be produced during plant-pathogen interactions suggests its direct role as an antimicrobial agent and as the cause of localized membrane damage at the site of nematode infection. $M$. incognita infestation leads to the production of superoxide anion $\left(\mathrm{O}_{2}^{-}\right)$in tomato. In susceptible cultivars these are scavenged by the increased superoxide dismutase (SOD) activity (Zacheo and Bleve-Zacheo, 1988). In resistant cultivars the relative inactivity of SOD produced an increase in the superoxide anions, this is considered as a possible cause of cell necrosis and the hypersensitive reaction which is common to many resistant plants.

Generally, incompatibility to nematodes expressed after infection and the active mechanisms involved compounds produced postinfectionally rather than performed constitutive plant products (Kaplan and Keer, 1980). Accordingly, plants develop defense mechanisms right away after nematode invasion. Most of these defense mechanisms are incompatible resistant interactions between plants and pathogens of which the formation of reactive oxygen species (ROS) are common (Montes et al., 2004). Such reactive oxygen species induced lipid peroxidation accounting for cell death after pathogen invasion. Hence increasing the rates of MDA and $\mathrm{H}_{2} \mathrm{O}_{2}$ in tomato infected plants in the present study as compared to uninfected healthy plants accounted for the defense mechanism against the invasion by the root-knot nematode, Meloidogyne incognita. Such assumption is evidenced by the application of fertilizers which reduced ROS to be near to those in healthy plants. The organic fertilizers, especially compost 3 which accomplished nematode control reached $80 \%$ were effective than inorganic fertilizers in reducing ROS. Application of nem- 
acur, in spite of reducing nematode population, did not reduce plant content of peroxidases. The nematicide raised MDA by 610 and $228 \%$ in tomato shoots and roots, respectively over those in the untreated healthy plants. This may be due to the direct effect of the nematicide on the nematode and not to indirect effect through physiological alterations in the host plant. Yet, the presence of the toxic metabolites of the nematicide in plant cells gap may be the reason for increasing plant contents of peroxidases. These findings are in accordance with those of Gregory and Michael (1978), Mazzafera et al. (1989), Sundararaju and Suba (2006) and Kesba and El-Beltagi (2012), who reported that nematodes infections escalated contents of peroxidases in host plants.

Infected tomato plants exhibited both enzymatic and non-enzymatic antioxidant defense systems to frustrate ROS upon nematode infection. The significant increase of non enzymatic antioxidants such as glutathione (GSH) and total ascorbic acid may be resulted from the enhancement of $\mathrm{MDA}$ and $\mathrm{H}_{2} \mathrm{O}_{2}$ production after nematode infection. In the present study, nematode infection resulted in slight but significant increase in both glutathione and ascorbic acid in tomato shoots and roots. Nemacur increased percentages of glutathione by 56.1 and $51.2 \%$ and ascorbic acid by 28.7 and $22.6 \%$ in shoots and roots, respectively. However, treating infected plants with fertilizers accomplished higher percentages of increments with superiority to organic fertilizers especially compost 3 which achieved the highest percentages of plant protection against the root-knot nematode, Meloidogyne incognita.

The role of ascorbic acid in plant defense mechanisms against nematodes was illustrated by Arrigoni et al. (1979). They reported that ascorbic acid depletion in plants attenuated resistance in tissues to nematode infections. They hypothesized that plants utilized ascorbic acid for the synthesis of mitochondrial hydroxyproline proteins which control the development of cyanide resistant respiration. They also stated that the amount of ascorbic acid in susceptible plant was unaltered by nematode attacks, but in resistant plants, ascorbic acid synthesis always was stimulated. Accordingly, organic fertilizers used in the present study, especially compost 3 and neem induced some resistance to the susceptible tomato plants by stimulating the synthesis of ascorbic acid. Ascorbic acid induced resistance against $M$. incognita in soybean and sunflower, so that they recommended the use of ascorbic acid to elevate the resistant ability of susceptible plants (Moawad, 2005; Saeed, 2005). Arrigoni (1979) also hypothesized that cyanide-resistant respiration (CRR), commonly associated with wounds is requisite to the activations of biological defense mechanisms. Ascorbic acid-dependant synthesis of hydroxyproline-containing protein is associated with $\mathrm{CRR}$ in mitochondria. Cyanide resistant respiration generates hydrogen peroxide from which superoxide is generated by peroxidase. Superoxides are extremely toxic and can diffuse through cells to oxidize functional groups of enzymes and phospholipids, reduce S-S bonds and cause macromolecule and membrane injuries.

In the present study, nematode infection increased glutathione and ascorbic acid. Treating infected plants with fertilizers resulted in higher percentages of increase which stimulate the production of non-enzymatic antioxidants, superoxide dismutase (SOD), ascorbate peroxidase (APX) and catalase (CTA) in tomato shoots and roots. Also the organic fertilizers, compost 3, neem and poultry droppings, in that order accomplished the highest rates of increase. Superoxide dismutases (SOD) normally function to limit superoxide concentrations. During CRR, SOD activities diminishes and accumulates superoxides and suppress parasite development and kill plant cells (Arrigoni, 1979). He proposed that nematode-incompatible plants are capable of early induction of an increase rate of CRP following infection.

Ascorbate peroxidase (APX) and catalase (CAT) as well as (SOD) are responsible for scavenging the excess of active oxygen species (ROS) in plant cells. Catalase and ascorbate peroxidase play an essential role in scavenging the toxicity of $\mathrm{H}_{2} \mathrm{O}_{2}$. The combined action of CAT and SOD converts the toxic superoxide radical $\left(\mathrm{O}_{2}^{-}\right)$and hydrogen peroxide $\left(\mathrm{H}_{2} \mathrm{O}_{2}\right)$ to water and molecular oxygen $\left(\mathrm{O}_{2}\right)$, thus evading the cellular damage under nematode infection (Asada, 1992; Zacheo and Bleve-Zacheo, 1988).

The enzymatic antioxidants also involved in defense mechanisms of plants against nematodes. The present results indicated that Glutathione-S-transferase (GST) increased to very high levels in plants infected with nematodes or those infected and treated with nemacur. Treating infected plants with fertilizers reduced the levels of the enzyme in shoots and roots significantly. Also, compost 3 was the best followed by neem, then compost 1 came statistically in the third category.

Phenylalanine ammonia lyase (PAL) increased by nematode infection slightly (but significantly) as compared to healthy plants. Similarly, organic fertilizers tremendously increased the enzyme activity in infected plants offering high degrees of protection from nematode invasion and development. The activity of the enzyme is higher in roots than in shoots of infected tomato. Phenylalanine ammonia lyase activity is higher in resistant than in susceptible plant (Gerald et al., 1998; Wuyts et al., 2006). These findings illustrated the rode of fertilizers especially organic, in elevating the resistance ability of treated plants and reducing nematode populations to levels near to those achieved by the nematicide. The good results accomplished by compost either in improving plant growth or hindering nematode populations by inducing some resistance to infected plants through activating plant enzymes emphasized the beneficial effects of compost described by the Field Guide to Compost Use (2001) and by Evanylo et al. (2008), Ahmed et al. (2009) and Rashad et al. (2010). 
140

\section{Acknowledgments}

Authors would like to thank the management of the Faculty of Agriculture, Cairo University for ongoing cooperation to support research for providing funds and facilities necessary to achieve the desired goals of research.

\section{References}

Afify AMR, El-Beltagi HS (2011a). Effect of the insecticide cyanophos on liver function in adult male rats. Fresen Environ Bull 20(4a):1084-1088.

Afify AMR, El-Beltagi HS (2011b). Discharge of lead contamination by natural compounds Pectin and Chitin: Biochemical analysis of DNA, RNA, their DNase, RNase and GOT in albino rat as an early bio-marker of leadtoxicity. Asian Pac J Trop Biomed S225-S230.

Afify AMR, El-Beltagi HS, Fayed SA, Shalaby EA (2011a). Acaricidal activity of successive extracts from Syzygium cumini L. Skeels (Pomposia) against Tetranychus urticae Koch. Asian Pac J Trop Biomed 1(5):359-364.

Afify AMR, Rashed MM, Ebtesam AM, El-Beltagi HS (2011b). Effect of gamma radiation on protein profile, protein fraction and solubility's of three oil seeds: soybean, peanut and sesame. Not Bot Horti Agrobo 39(2):117-123.

Ahmad N, Hassan F, Belford R (2009). Effects of soil compaction in the sub-humid cropping environment in Pakistan on uptake of NPK and grain yield in wheat (Triticum aesitivum) II, Alleviation. Field Crops Res 110:61-68.

Aly AA, El-Beltagi HS (2010). Influence of ionizing irradiation on the antioxidant enzymes of Vicia faba L. Grasas y Aceites 61(3):288-294.

Arrigoni O (1979). A biological defense mechanism in plants. 457-467 p. In: Lamberti F, Taylor CE (Eds). Root-Knot Nematodes (Meloidogyne species) Systematic, Biology and Control. New York: Academic Press.

Arrigoni O, Zacheo G, Arrigoni-Liso R, Bleve-Zacheo T, Lamberti F (1979). Relationship between ascorbic acid and resistance in tomato plants to Meloidogyne incognita. Phytopathol 69:570-581.

Asada K (1992). Ascorbate peroxidase a hydrogen peroxidescavenging enzyme in plants. Physiol Plantarum 85:235241.

Beauchamp C, Fridovich I (1971). Superoxide dismutase: improved assays and assay applicable to acrylamide gels. Anal Biochem 44:276-287.

Borden S, Higgins VJ (2002). Hydrogen peroxide plays a critical role in the defense response of tomato to Cladosporium fulvum. Physiol Mol Plant Pathol 61:227-236.

Bradford MM (1976). A rapid and sensitive method for the quantification of microgram quantities of protein utilizing the principle of protein-dye binding. Anal Biochem 72:248254.

Capaldi DJ, Taylor KE (1983). A new peroxidase color reaction: oxidative coupling of 3-methyl-2-benzothiazolinone hydrazone (MBTH) with its formaldehyde azine application to glucose and choline oxidases. Anal Biochem 129:329336.

Davis EL, Hussey RS, Baum TJ, Bakker J, Schots A, Rosso MN, Abad P (2000). Nematode parasitism genes. Ann Rev Phytopathol 38:365-396.

De Vos CH, Vonk M, Vooijs JR, Henk S (1992). Glutathione depletion due to copper-induced phytochelatin synthesis causes oxidative stress in Silene cucbalus. Plant Physiol 98:859-858

El-Beltagi HS, Salama ZA, El-Hariri DM (2008). Some Biochemical Markers for Evaluation of Flax Cultivars under Salt Stress conditions. J Nat Fibers 5(4):316-330.

El-Beltagi HS, Mohamed AA, Rashed MM (2010). Response of antioxidative enzymes to cadmium stress in leaves and roots of Radish. Not Sci Biol 2(4):76-82.

El-Beltagi HS, Mohamed AA (2010). Changes in non protein thiols, someantioxidantenzymes activities and ultrastructural alterations in Radish plants (Raphanus Sativus L.) grown under lead toxicity. Not Bot Horti Agrobo 38(3):76-85.

El-Beltagi HS, Ahmed OK, El-Desouky W (2011a). Effect of low doses $\gamma$-irradiation on oxidative stress and secondary metabolites production of Rosemary (Rosmarinus officinalis L.) callus culture. Radiat Phys Chem 80(9):968-976.

El-Beltagi HS, Kesba HH, Abdel-Alim AI, Al-Sayed AA (2011b). Effect of root-knot nematode and two species of crown gall on antioxidant activity of grape leaves. Afr J Biotechnol 10(57):12202-12210.

Eriyamremu GE, Lolodi O (2010). Alterations in lipid peroxidation and some antioxidant enzymes in germinating beans (Vigna unguiculata) and maize (Zea mays) Exposed to Nickel. Inter J Bot 6(2):170-175.

Essemine J, Ammar S, Bouzid S (2010). Impact of heat stress on germination and growth in higher plants: Physiological, biochemical and molecular repercussions and mechanisms of defence. J Biol Sci 10(6):565-572.

Evanylo G Sherony C, Spargo J, Starner D, Brosius M, Haering $\mathrm{K}$ (2008). Soil and water environmental effects of fertilizer, manure and compost-based fertility practices in an organic vegetable cropping system. Agric Ecosys Environ 127:5058.

Farahat AA, Alsayed AA, El-Beltagi HS, Mahfoud NM (2012). Impact of organic and inorganic fertilizers on nematode reproduction and biochemical alterations on tomato. Not Sci Biol 4(1):58-66.

Field Guide to Compost Use. (2001). Field Guide To Compost Use. U.S. Composting Council, 1 Comac Loop, Suite 14 Bl Ronkonkoma, New York, 1779 p.

Gerald DB, Nichole RO, Deborah AS (1998). Alfalfa (Medicago sativa L.) resistance to the root-lesion nematode, Pratylenchus penetrans: defense response gene mRNA and isoflavonoid phytoalexin levels in roots. Plant Mol Biol 38:999-1010.

Gregory RN, Michael AM (1978). Peroxidase and 
6-phosphogluconate Dehydrogenase in resistant and susceptible cotton infected by Meloidogyne incognita. J Nematol 10:34-39.

Halliwell B, Gutteridge JMC (1999). Free radicals in biology and medicine, $3^{\text {rd }}$ Ed. Oxford University Press Oxford.

Hasan N, Saxena SK (1997). Effect of inoculating tomato with root-knot nematode, Meloidogyne incognita on phenolic content and polyphenol oxidase activity. Physiol Host Pathogen Interact Curr Trends Life Sci 6:199-203.

Haraguchi H, Saito T, Okamura N, Yagi A (1995). Inhibition of lipid peroxidation and superoxide generation by diterpenoids from rosmarinus offcinalis. Planta Med 61:333-336.

Hefny M, Abdel-Kader DZ (2007). Antioxidant-Enzyme System as Selection Criteria for Salt Tolerance in Forage Sorghum Genotypes (Sorghum bicolor L. Moench). Inter J Plant Breed Genet 1(2):38-53.

Huang G, Dong R, Maier T, Allen R, Davis EL, Baum TJ, Hussey RS (2004). Use of solid-phase subttactive hybridization for the identification of parasitism gene candidates from the root-knot nematode Meloidogyne incognita. Mole Plant Pathol 5:217-222.

Ibrahim NM, Eweis EA, El-Beltagi HS, Abdel-Mobdy YE (2011). The effect of lead acetate toxicity on experimental male albino rat. Biol Trace Elem Rese 144:1120-1132

Kaplan DT, Keer NT (1980). Mechanisms conferring plant incompatibility to nematodes. Revue de Nematologica 3:123-134.

Kesba HH, El-Beltagi HES (2012). Biochemical changes in grape rootstocks resulted from humic acid treatments in relation to nematode infection. Asian Pac J Trop Biomed 2(4):287-293.

Kobeasy MI, El-Beltagi HS, El-Shazly MA, Khattab EAH (2011). Induction of resistance in Arachis hypogaea L. against Peanut Mottle Virus by nitric oxide and salicylic acid. Physiol Mol Plant Pathol 76:112-118.

Mannervik B, Guthenberg C (1981). Glutathione transferase (Humanplacenta). Methods Enzymol 77:231-235.

Mazzafera P, Goncalves W, Fernandes JAR (1989). Phenols, peroxidase and polyphenol oxidase in the resistance of coffee to Meloidogyne incognita. Bragantia 48(2):131-142.

Melillo HT, Leonetti P, Bongiovanni M, Castagnone-Seeno P, Bleve-Zacheo T (2006). Modulation of reactive oxygen species activities and $\mathrm{H}_{2} \mathrm{O}_{2}$ accumulation during compatible and incompatible tomato root-knot nematode interactions. New Phytol 170:501-512.

Mellersh DG, Foulds IV, Higgins VJ, Heath M (2002). $\mathrm{H}_{2} \mathrm{O}_{2}$ plays different roles in determining penetration failure in three diverse plant-fungal interactions. Plant J 29:257-268.

Mishra CD, Mohanty KC (2007). Role of phenolics and enzymes in imparting resistance to rice plants against rootknot nematode, Meloidogyne graminicola. Ind J Nematol 37(2):131-134.

Moawad MM (2005). Studies on nematode pests associated with some oil crops and their control methods. Ph.D. Thesis. Fac. Agric., Al-Azhar Univ., Egypt, 82 p.

Mohamed AA, El-Beltagi HS, Rashed MM (2009). Cadmium stress induced change in some hydrolytic enzymes, free radical formation and ultrastructural disorders in Radish plant. EJEAF Chem 8(10):969-983.

Molinari S (1995). Difference in isoperoxidase activities of tomato roots susceptible and resistant to root-knot nematodes. Nematologia Mediterranea 23(2):271-281.

Molinari S, Miacola C (1997). Catalase induction in galls produced by Meloidogyne sp. tomato root interactions in vitro. Nematologia Mediterranea 25(2):299-303.

Montes MJ, Lopez-Brana I, Delibes A (2004). Root enzyme activities associated with resistance to Heterodera avenae coferred by gene Cre7 in wheat, Aegilops triuncialis introgression line. J Plant Physiol 161:493-495.

MSTAT-S (1989). Statistical package software program for the design and analysis of research experiment, Michigan State University, USA.

Nagesh V, Welch KM, Windham JP, Patel S, Levine SR, Hearshen D, Peck D, Robbins K, D’Olhaberriague L, Soltanian-Zadeh H, Boska MD (1998). Time course of ADCw changes in ischemic stroke: beyond the human eye! Stroke 29:1778-1782.

Nakano Y, Asada K (1981). Hydrogen peroxide is scavenged by ascorbate specific peroxidase in spinach chloroplasts. Plant Cell Physiol 22:867-880.

Ochoa-Alejo N, Gomez-Peralta JE (1993). Activity of enzymes involved in capsaicin biosynthesis in callus tissue and fruits of chili pepper (Capsicum annuum L.). J Plant Physiol 141:147-152.

Patel BA, Patel DJ, Patel RG, Talati JG (2001). Biochemical changes induced by infection of Meloidogyne spp. in chickpea. ICPN (8):13-14.

Rashad FM, Saleh WD, Moselhy MM (2010). Bioconversion of rice straw and certain agro-industrial wastes to amendments for organic farming systems. I-composting, quality, stability and maturity indcies. Bioresource Technology 101:59515960.

Reddy AM, Kumar SG, Jyothsnakumari G, Thimmanaik S, Sudhakar C (2005). Lead induced changes in antioxidant metabolism of horsegram (Macrotyloma uniflorum (Lam.) Verdc.) and bengalgram (Cicer arietinum L.). Chemosphere 60:97-104.

Saeed MRM (2005). Utilization of some specific materials to stimulate resistance in some host plants against the rootknot nematodes. Ph. D. Thesis. Cairo Univ. Egypt, 220 p.

Salama ZA, El-Beltagi HS, El-Hariri DM (2009). Effect of Fe deficiency on antioxidant system in leaves of three flax cultivars. Not Bot Horti Agrobo 37(1):122-128.

Saleh AAH (2007). Amelioration of Chilling Injuries in Mung Bean (Vigna radiata L.) Seedlings by Paclobutrazol, Abscisic Acid and Hydrogen Peroxide. Am J Plant Physiol 2(6):318332. 
142

Sharma ON (1993). Enhancement of biological defense mechanisms in resistance and its activation in susceptible tomato cultivars infested with root-knot nematode, Meloidogyne incognita. Plant Dis Res 8:47-53.

Shehab GMG, Ahmed OK, El-Beltagi HS (2010). Nitric oxide treatment alleviates drought stress in rice plants (Oryza sativa). Not Bot Horti Agrobo 38(1):139-148.

Shukla YM, Chakraborty MK (1988). Biochemical studies on response of tobacco and tomato plants to root-knot nematode infection. Tobacco Res 14(1):43-50.

Singh N, Ma LQ, Srivastava M, Rathinasabapathi B (2006). Metabolic adaptations to arsenic-induced oxidative stress in Pteris vittata L. and Pteris ensiformis. L. Plant Sci 170:274282.

Sundararaju P, Suba KP (2006). Biochemical changes in banana plants induced by Pratylenchus coffeae and Meloidogyne incognita. Ind J Nematol 36(2):256-259.

Wuyts N, De Waele D, Swennen R (2006). Activity of phenylalanine ammonia-lyase, peroxidase and polyphenol oxidase in roots of banana (Musa acuminate AAA, CVs 'Grande Naine' and 'Yangambikm 5' before and after infection with Radopholus similis). J Nematol 38(2):201-209.
Xu, Xiao Ming, Xu Kun, Yu Qin, Zhang-Xiaoyan (2008). The relationship between resistance to Meloidogyne incognita and phenylpropanes metabolism in roots of eggplant rootstock. Acta Phytophylacica Sinica 35(1):43-46.

Zacheo G, Bleve-Zacheo T (1988). Involvement of superoxide dismutase and superoxide radicals in the susceptibility and resistance of tomato plants to Meloidogyne incognita attack. Physiol Mol Plant Pathol 32:313-322.

Zacheo G, Bleve-Zacheo T, Pricolo G, Zacheo TB (1987). Metabolic changes in enzyme levels in potato roots infested by potrato-cyst nematode, Globodera pallida (Pa3) and Globodera rostochiensis (R01). Nematologia Mediterranea 15(2):293-302.

Zacheo G, Orlando C, Belve-Zacheo T (1993). Characterization of anionic peroxidases in tomato isolines infected by Meloidogyne incognita. J Nematol 25(2):249-259. 